\title{
Sun and moon grinding to a halt: \\ Exegetical remarks on Joshua 10:9-14 and \\ related texts in Judges
}

\author{
H A J Kruger \\ Faculty of Theology \\ University of Durban-Westville
}

\begin{abstract}
Attempts to solve the enigma of the extended day may be classified into two groups. Several interpretations are based on the natural sciences. Recently, however, as far as the construction of the passage is concerned, renewed attention has been given to the possible role of religious customs, mythology and omens in connection with ancient military strategy. Against this background, the sun and moon are viewed as deities and told to remain passive in the battle. Omen texts from Mesopotamia related to warfare, and based on the "favourable" or "unfavourable" position of the sun and moon, seem to have impacted on the passage as well. Others have interpreted the sun in terms of mythical and/or theological categories. This paper avers that an interpretation in terms of the mythical millwheel may help to explain the meaning of the passage.
\end{abstract}

\section{INTRODUCTION}

\subsection{The fate of the sun}

Generally speaking, the relationship between the fate of the sun, and disaster which follows in its wake, was a common idea in ancient myths. According to some Central American traditions, at the time of cataclysms, the sun deviates from its regular path, the sky falls, the earth is wrenched and torn by earthquakes, and finally a wave of water engulfs the globe. According to an American Indian tribe (the Utes), the hare god fired a 
magic arrow at the sun, causing it to shatter into pieces and earthquakes and floods to engulf the earth. Many similar legends suggest that some great catastrophe was preceded by a change in the face of the sun (for example an eclipse), or that a catastrophe had obscured the sun for a long time (Wilson 1997:117, 121).

\subsection{Legend of a long day}

However, more to the point, support for what appears to be a miracle as presented in the present passage has been reported in folklore throughout the world, in legends of a day when the sun did not set. In ancient Chinese writings, there is a legend of a long day in the reign of Emperor Yeo. The same applies to the writings of the Incas of Peru and the Aztecs of Mexico. Babylonian and Persian legends refer to a day that was miraculously extended. Herodotus recounts that the priests of Egypt showed him their temple records, and that there he read a strange account of a day that was twice the natural length (Boling \& Wright 1982:287-288; LaSor, Hubbard \& Bush 1982:209; Kang 1989:158; Soggin 1972:122; Weinfeld 1978:171-181; 1984:121-147; Rimmer 1952: 269-271). The legend of a long (or extended) day thus seems to have been well established among the ancients.

\section{A MYTHICAL-ASTRONOMICAL DEVICE}

\subsection{A mythical-astronomical key}

The interrelatedness of the texts dealing with the stationary position of the sun and moon on the one hand, and the downpour of (hail)stones on the other, as well as other possible references to cosmological occurrences in Joshua (and Judges), may lead the exegete to interpret the passage not only in terms of the legend of a long day, but also in terms of a mythical-astronomical key adjusted to serve its theological intent.

Apparently the impact of North and West European traditions on the shaping of biblical literature has been limited, by and large, to a comparison of the literary type of the saga (particularly the Icelandic saga), with a possible similar biblical genre (Neff 1985:17-32). However, the scope of investigation should be broadened to include the world of myth. It is vital to the understanding of the present passage that the possible, 
albeit partial, influence of ancient North and West European mythical traditions forms part of this exercise.

The Bronze/Iron Age provides the wider common background which links the religious and mythical world of these traditions and the present passage (cf Jos 6:19; 22:8). The Scandinavian Bronze Age ( $\pm 1600-450 \mathrm{BC})$ overlaps, to a certain extent, with Syria-Palestine's Middle Bronze Age IIB through the Babylonian/Persian period $( \pm 1750$ 350 BC). The latter period encapsulates the Palestinian Late Bronze/Iron Age, and covers the time when the events recorded in Joshua (and Judges) probably took place (Ellis-Davidson 1996:6; Hayes \& Miller 1977:90-91).

\subsection{The myth of the millwheel}

With this in mind, the paper avers that the portrayal in Joshua 10:12b-13 evokes especially the ancient myth of the rotating millstone (De Santillana \& Von Dechend 1969:8695, 137-148, 313; see Metford 1983:174, 254). Aspects of this myth may have influenced other parts of the Old Testament as well (see Kruger 1998: 399-411). To a certain extent, the present study was influenced by the work of De Santillana \& Von Dechend, two scholars in the history of science. According to De Santillana \& Von Dechend, the time of the origin(s) of this myth cannot be determined, as is the case with all myths. However, traces of the millstone as a mythical device can be found in Greek literature (Cleomedes 1.7, ca $150 \mathrm{BC}$ ). According to these authors, a reasonable case has been made for the extreme antiquity and continuity of certain traditions concerning the heavens. They maintain that the individual myths of "Amlodhi's Quern", the "Grotte", and the "Sampo" (see Cotterell 1996:2, 196-197, 221, 241), which are different versions of the myth of the millstone, can be traced to and were derived from ancient North and West European and/or Near Eastern astronomical traditions. These authors cite sources which depict the orb of heaven rotating like a millstone around its axis, and ever does something bad. It was not a foreign idea to the ancients that the mills of the gods grind slowly, and that the result is usually pain. This statement contains an important idea related to the myth of the turning millwheel. The revolving heavens provided the key for the myth. The circular movement of the celestial bodies is portrayed as a rotating millstone (De Santillana \& Von Dechend 1969:60, 111, 137-139). 
One example should suffice to illustrate the point. In these myths, the turning of a mill or quern ground out gold, peace and plenty. In many of the traditions, two maidens, Fenja and Menja are indentured to turn such a millwheel. Something goes awry and while everyone was asleep, the two giantesses turn the mill at such a speed that its props, though cast in iron, give way. Later the mill is stolen, the turning has to continue under new management, grinding out salt; still later the millstone sinks to the bottom of the sea, now grinding out rocks and sand, and creating a whirlpool, the Malstrom. According to De Santillana \& Von Dechend, there are indications that this picture of a rotating millwheel, breaking free from its props and causing disaster, represents respectively the luminous dome of the rotating celestial sphere, including the earth, and interruption of this rotation by cosmological disaster.

\subsection{The millwheel and scientific facts}

Santillana \& Von Dechend maintain that these archaic myths, especially those in connection with the millwheel, contain or conceal in terms of an allegory or a thought tool, information about scientific established phenomena. This means representing the frame of a world age or a system for veiling technical terminology of an advanced astronomical science behind the everyday language of myth. Thus currently, certain ancient myths, including the one of the millstone, are viewed by certain authors as vehicles of scientific facts. The concepts used in myths are irrelevant as far as cosmological terminology is concerned, but mythical language provided the linguistic vehicle which was used to carry the ideas of astronomy. The recorded events of heaven could survive only through fragments of myth and tale, because these made up the only technical language of those times (De Santillana \& Von Dechend 1969:60, 111, 137-148).

\subsection{The millwheel and star trails?}

The portrayal of the orb of heaven as a millwheel may be related to the simple observation that, looking at the sky at night from the earth's point of view, the starry heavens seem to be rotating around a pivot. As the earth rotates, the stars in the sky seem to revolve around the North (and South) Pole stars. The rotation can be seen from modern day photographic images taken at night. With a long-exposure photograph it is possible 
to capture this slow motion which creates star trails (Spence 1997:61). The photograph shown in Spence's book, captured 45 minutes' exposure time. (For another remarkable photo illustrating this effect see Gribbin \& Goodwin 1997:11.) The people of the distant past meticulously studied and had intimate knowledge of the heavens (see Heyns 1997: 252-267), and probably had knowledge of this phenomenon (Bauval \& Gilbert 1996:198201). Thus the possibility that the ancients had at their disposal knowledge of these celestial movements must be considered, when attempting to explain the present passage. But whether the observation of star trails can be used to explain the presentation of the sun and moon as part of a rotating starry sky in this text, and especially their coming to a halt, remains a moot question.

\subsection{The millwheel and the precession of the equinoxes}

On the other hand, this presentation based on star trails may have merit in the light of the perhaps little known fact that the ancients imagined the sphere of heaven as a turning millwheel, with the North Pole as the axle-bearing in which the mill-iron turns. On this basis, the portrayal of the mythical turning millwheel, which is identified with the rotating heavens, and appears in a welter of traditions, is understood as a veiled expression of the scientific established astronomical phenomenon of the precession of the equinoxes (see Pearsall \& Trumble 1996:1138-1139). (Precession represents the motion of a spinning body such as a top, gyroscope, or planet, in which it wobbles so that the axis of rotation sweeps out a cone). Hartner (1965:1-16) claims that the ancients made accurate astronomical observations around $4000 \mathrm{BC}$, the time of the first Elamite and Mesopotamian settlements. But he denies, along with others, the claim made by certain authors, that the people of the distant past were familiar with the astronomical phenomenon of the precession of the equinoxes as a systematic continuous variation, (his italics), before Hellenistic times. As was mentioned earlier, the Greek astronomer Cleomedes mentioned the device of the turning millstone (I.7, see above), but it is not clear whether he had any knowledge of the precession of the equinoxes and/or what the extent of that knowledge was (Kroll 1921: 682). According to Jordan (1995:19) at the rise of mythologies, scientific evidence (like the earth orbiting the sun) is not available to the storytellers. He goes on to say, however, that cosmic events, including eclipses, or other traumatic events 
during which the sun or the moon falls to earth before being restored to the heavens, are often reflected in myth. However, there seems little doubt that in ancient times, myth and established scientific facts regarding natural phenomena were linked with each other. In Anglo-Saxon England it was the fiery dragon, breathing out flame and passing over the habitations of men like a dangerous comet shedding fire, which was the dominant image. In the Chronicle of the Anglo-Saxons, shooting stars and comets were said to be fiery dragons flying through the air, signs of ill-omen (Ellis-Davidson 1996:116, 120). Thus, the current view that the Greek astronomer Hipparchus discovered the precession of the equinoxes around 134 BC (Wissowa 1896:1850-1851; Ziegler \& Sontheimer 1964:666; Magnusson 1996:713), is challenged by others who allege that the knowledge of this phenomenon dates back much further (De Santillana \& Von Dechend 1969:142; Hancock 1996:256, 275-276).

\subsection{Some detail: Why a mill?}

In order to come to a better understanding of these ideas, a more detailed look at the work of De Santillana \& Von Dechend is in order. The basic argument of their book, Hamlet's Mill, runs as follows. The ancients not only knew about the precession of the equinoxes, but encoded this knowledge in dozens of myths, because they did not have a system in which they could present their ideas. De Santillana \& Von Dechend found similar myths among the traditions of a host of ancient peoples. This led them to surmise a common origin for these myths, namely astronomy. The point of departure of these myths is a corn-grinding mill that belonged to the Icelandic Hero Amlodhi, whose name has come down to us as Hamlet. Originally, that is, in the "Golden Age", this mill ground out peace and plenty. This came to a disastrous end and the mill then ground out salt. Finally, it ended up at the bottom of the sea, grinding out sand, and creating the whirlpool called the Malstrom ("Mala" is related to grind).

Why a mill? Presumably because one grinding wheel, the sun, goes through the constellations in one direction - Aries, Taurus, Gemini, et cetera - while the equinoxes move in the opposite direction - Gemini, Taurus, Aries, et cetera. What was embodied in the mill was the idea of "catastrophes and the periodic rebuilding of the world". Thus ancient myths are about catastrophes like the Flood. But the "ages" that end in catas- 
trophe, are due to the precession of the equinoxes which means that we move from age to age - the Age of Leo $10000 \mathrm{BC}$ down to our present Age of Pisces, and the coming Age of Aquarius. Obviously, if the ancients thought that the precession of the equinoxes was connected with periodic great catastrophes that destroyed a large part of humankind, they would attach great importance to it, and study it minutely. According to De Santillana \& Von Dechend (1969:56-75, 142), Amlodhi's mill is an image of the precession of the equinoxes (see Wilson 1997:277-279). The attention given by the ancients to the precession of the equinoxes relates to the conception that the universe/the earth moves through ages constantly, beginning with a "new creation" and ends with its destruction. Such a new age (and its demise) is demarcated by the movement of the earth through the different signs of the zodiac, i e the crossing over from one house to the other marks the end/beginning of another age. This switch of the equinoctial point from one constellation to another, that is, the end of one age and the beginning of a new one, was regarded by the ancients as an alarming event (De Santillana \& Von Dechend 1969:141-142; Wilson 1997: 286). According to some authors, when a cycle of this movement of the earth's axis is completed (which takes about 26000 years), cosmic and global disturbances may take place. Regarding the first, this could include stars being thrown out of kilter. Respecting the second, a slipping of the earth's crust over its inner core is possible, or the shifting of the poles of the earth (Hancock 1996:239-251). The conclusion in connection with the possible shifting of the earth's poles comes from the scientist Albert Einstein (De Santillana \& Von Dechend 1969:493-495). However, this paper does not endeavour to prove or disprove these statements, rather it is concerned with the style of mythical presentation.

It is important to take notice of some of the components of the myth of the rotating millstone. According to the myth, at a certain stage the rotating millstone comes to a halt. The millwheel is presented as being unhinged, spinning out of control, stopping, being wrecked and causing disaster. The slightly earlier occurrence of the equinoxes each year, due to the slow continuous shift of the equinoctial points along the ecliptic, that is the shifting of the world axis, is seen as the cause of the unhinging of the millwheel. Motion is the medium by which the wrecking is brought about (De Santillana \& Von Dechend 1969:146). It has been predicted that in such a situation the earth's axis 
may tilt, causing catastrophic famine and disease (Procter 1995:87). This disaster allegedly strikes the cosmos including the earth, with devastating results (De Santillana \& Von Dechend 1969:140). As was noted above, this may include serious disruptions of the movement of the sun, moon, stars, and the earth.

\subsection{Suspicion}

Naturally in the mind of the critical reader, these statements arouse suspicion. However, the present reasoning is not dependent on whether these views are scientifically verifiable or not. On the other hand, the Old Testament does mention the shaking of heaven and earth/land and sea, and other astronomical occurrences (e $\mathrm{g}$ Is 13:10, 13; 24:18b-20a; Ezk

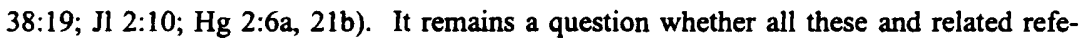
rences must be understood in a metaphorical manner alone.

\subsection{Points of contact}

Comments by scientists monitoring the phenomenon of the precession of the equinoxes, and the interpreters of the myth of the millwheel, indicate a certain overlap between the behaviour of celestial bodies, on the one hand, and that of the millstone, on the other. In both cases reference is made, inter alia, to the stopping of the rotating movements of the object(s) (earth/sun, moon and stars//millwheel). In both cases disaster follows this occurrence (cosmic disaster/breaking of the millstone), and in both cases the cosmos and the earth/living beings seem to be involved in a particular way. Another striking way by which a link between the myth and an aspect of this scientific phenomenon is established, that is, between the behaviour of the millstone and the precession of the equinoxes, finds expression in numbers, a concept which played an important role in ancient literature. The figure 4320 represents the number of years required for the equinoctial sun to complete a precessional shift of 60 degrees, that is, 2 zodiacal constellations. The number 2 $160(4320 \div 2)$ represents the number of years required for the sun to pass completely through one of the 12 zodiacal constellations; $2160 \times 12=25920$, the number of years in one complete precessional cycle. Veiled in various ways, this number constantly crops up in, for example Egyptian myth (cf the number of the conspirators in the Osiris myth: $72 \times 60=4320$ ), and Norse myth (cf the 432000 fighters who sallied forth from 
Valhalla to do battle with the wolf, Fenrir. The latter chases the sun, overtakes it and extinguishes its rays, whereupon disaster strikes the earth, the earth loses its shape, and the stars coming adrift in the sky. Thus the theme of catastrophe is mixed with the quite separate theme of precession). In ancient Chinese traditions, references to a universal cataclysm were said to have been written down in a text containing 4320 volumes. The Babylonian historian Berossus (3rd century BC) ascribed a total reign of 432000 years to the mythical kings who ruled the land of Sumer before the great flood. The latter author ascribed 2160000 years $(=4320000 \div 2)$ to the period between creation and universal catastrophe (See Hancock 1996:262, 273-276).

Set in a wider context, another factor to be reckoned with is the reality that at the end of the thirteenth century BC, the Late Bronze Age (in Syria-Palestine) came to an end with widespread upheaval in the Levant (Hayes \& Miller 1997:91). This factor may support the idea of a general awareness of comprehensive social, political, geological, and perhaps astronomical disturbances, which is reflected in the use of this particular mythical motif of the millwheel with its reputation of breaking up and creating disaster.

\section{A LONG DAY: SUN AND MOON GRINDING TO A HALT, AND DISASTER}

\subsection{Joshua}

The above observations open the way for the main argument of the paper, and shed light on Joshua 10:9-14. The text speaks of the sun and moon coming to a halt. The description evokes the idea of the mythical millwheel which represents the rotation of the starry sky, which comes to a standstill, and causes disaster.

\subsubsection{A construct}

The present construct avers that the simultaneous standstill of sun and moon as part of the greater starry sky, had as referent the stopping of the rotating millwheel in the myth. The millwheel is a wellknown object in the Old Testament (Dt 24:6, see 10-13, 17; also, Ex 32:20; Nm 11:8; Dt 9:21; Jdg 16:21; Is 3:15; 47:2; Jr 25:10; Lm. 5:13; Job 31:10; 41:15; 
Ec 12:3-4), and the New Testament (Mt 18:6; Rv 18:21). Some of these texts are reminiscent of the mythical millwheel (see below).

\subsubsection{Hailstones or celestial bodies?}

Secondly, the downpour of "big stones" respectively "hailstones" (Jos 10:11), could be related to the standstill of sun and moon in the sense that it may represent the result, the disaster part of the halting of the millwheel as found in the myth. Initially these objects hurled at or pouring down on the enemies of Israel are described as אבנים גדלות (big stones", v 11b). Subsequently these stones are qualified as באבני הברד ("hailstones", v 11c). Did the text in a "pre-canonical" stage contain a reference to stones only, in the sense of celestial objects from the skies? Perhaps these objects were later interpreted as "hailstones". That something special seems to be the matter here can be inferred from the extraordinary statement that so many people were killed by hailstones, specifically that more people were actually killed by hailstones than by the sword. This way of reasoning can be supported by a number of additional references to natural disasters, or at least disturbances, in the book of Joshua, used by Yahweh to accomplish his purpose with his people. Prior to the present narrative (i e Jos 10), at the time when the tribes of Israel were marching around Jericho for seven days (Jos 6), the description of the collapse of the city walls seem to indicate an earthquake (But see Durham 1987:270; cf Collins 1998: 1-104; Wilson 1998:330-335). Be that as it may, supernatural occurrences, somehow clothed in mythical garb, probably provided a framework for Yahweh's actions in the book of Joshua. The point to be taken is that the passage under discussion seems to be reaching back to a memory of some (mythical) portrayal of a cosmic occurrence related to the natural phenomenon of the precession of the equinoxes (see Ronan 1991:200).

\subsubsection{Stopping of sun and moon and other celestial occurrences}

The link between the stopping of the sun/moon and celestial occurrences in the Joshua passage is reminiscent of other ancient sources which deal with what appears to be similar material. Cohen (1988:427-439), followed by Walton (1994:181-190), cites from Mesopotamian incantation literature, and lines 10-15 from a first millennium balaglamentation, entitled: "He is a storm, At the healing": 
The heavens continually rumbled,

The earth continually shook,

The sun lay at the horizon

The moon stopped still in the midst of the sky

In the sky the great lights disappeared

An evil storm... the nations

A deluge swept over the lands (author's italics).

The relation between the stopping of the sun/moon and cosmic disaster in this lamentation must be noted.

\subsubsection{The millwheel and military action}

The relationship established in the text (Jos 10) between the behaviour of celestial bodies, in this construct represented as the stopping of the millwheel, and military action, is a further reminder of a particular feature of our myth. In the myth, disaster, which is the result of the halting of the millwheel, is related to soldiers taking part in the Ragnarok, the Norse version of the great battle of the end (De Santillana \& Von Dechend 1969: 162; see Hancock 1996:262). In the biblical narrative, the halting of sun and moon is directly linked to Joshua's military operation.

A description probably similar to the incident in Joshua appears in Greek literature. In Homer's Iliad II, 412-415, Agamemnon prays to Zeus not to let the sun go down

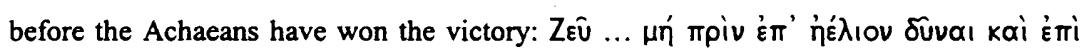

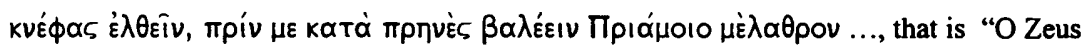
... (grant that) the sun set not, neither darkness come upon us, until I have cast down in headlong ruin the hall of Priam ...." (Leaf \& Bayfield 1971:38; Willcock 1970:61).

\subsubsection{Jericho and the millwheel}

It is thus possible that the idea of the mythical millwheel may be part of the make-up of these passages as well. Circumstantial evidence that could enhance or highlight this idea may be gleaned from a possible play on words in the context. Firstly, this suggestion perhaps gains support from the portrayal of the tribes of Israel milling (marching) around the walls of Jericho, followed by the disaster of the walls of the city collapsing, and the 
invasion. This presentation is reminiscent of the mythical millwheel, spinning, being unhinged, and disintegrating. Prior to this occurrence the waters of the Jordan came to a standstill (Jos 3:13, 16: 17ดעי).

\subsection{6 גלגל and the millwheel}

Secondly, the enigmatic meaning of the name of the place near Jericho where the tribes camped ( round ("circular") object in mind. Thirdly, the radix גלגל is related to the wheel-idea, another piece of evidence that reminds us of the millwheel in the myth. In declension this radix takes on the following meanings $\mathrm{I}$ : wheel of a war chariot (see Is 5:28; Ps 77:19; Ezk 10:2, 6, 13), or a well-wheel (Ec 12:6); II: a "wheel"-shaped plant (Is 17:13;

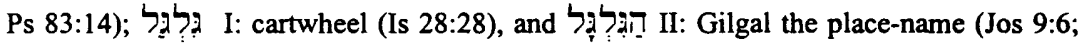

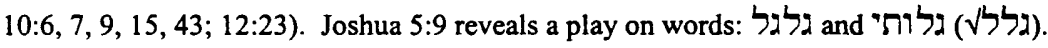

\section{$3.2 \quad$ Judges}

\subsubsection{A canonical connection}

A canonical connection exists between the books of Joshua and Judges (Childs 1979: 249), and between Judges and 1 Samuel respectively (Childs 1979:266-267). On this basis, the observation of possible wider influence from inter alia ancient North and West European myths in these books is not without warrant. Evidence for this view may be seen by comparing the following: Samson's use of the jawbone (of an ass) and Thor's use of the hammer (Page 1990:14) to the same effect. Samson's breaking the fetters (bowstrings/ropes) resembles the mythical Fenrir's action (p 16), and David flinging a stone and striking Goliath's forehead recalls the fragments of Hrungnir's shattered whetstone entering Thor's forehead ( $p$ 44). This may also be compared to the incident when Thor's hammer sank into the forehead of the giant Skrymir (Ellis-Davidson 1996:65). Thus it would seem that some resemblance exists between the world of North and West European myth and certain texts in Joshua, Judges and Samuel. 


\subsubsection{Star rain and flood}

It is important for the present discussion to make a few observations regarding the sequel to Joshua, namely the book of Judges. Judges states that the stars fought against Sisera (5:20). This could be a reference to a meteorite rain or shooting stars (Sawyer 1972:139146). If the latter refers to some cosmic occurrence or disaster of a number of meteorites striking the earth, the next statement in the text evokes the idea of a possible flood, which meant disaster for at least the enemies of Israel (5:21).

\subsubsection{The woman and the millwheel}

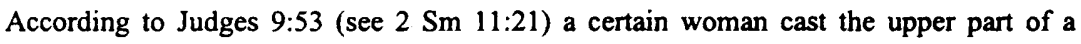
millstone down from the city tower crushing the sküll of Abimelech. The chain of events in this episode is noteworthy: a woman, a millstone, the millstone cast down, and causing disaster. These components are a direct reminder of the myth of the millstone: Fenja and Menja the two giantesses, turning the millwheel, the millstone becoming unhinged, falling into the sea, and causing disaster (De Santillana \& Von Dechend 1969:86-95).

\subsubsection{Samson and the millwheel}

A subsequent narrative is equally significant in this regard and displays the same pattern observed thus far. It states that Samson pulled the millstone (Jdg 16:21), followed by the disaster of the collapse of the temple of Dagon (Jdg 16:23-30; see Is 47:1-15; Jr 25:10; $51: 63-64 ; \operatorname{Rv} 18: 21-22$ ). It cannot be mere coincidence that these latter incidents, which are based on the myth in question, follow on the portrayal in Joshua. Further examples of Yahweh's action combined with natural disasters surround these passages. According to Judges 5:4,5 when Yahweh moved, the earth trembled, a statement coupled with a reference to the downpour of rain ( $\mathrm{v} 4 \mathrm{c}, 5 \mathrm{a})$. Compare the arrangement in the text: an earthquake - rain - earthquake. This is followed by a further reference to a cosmological framework when it is stated that by the waters of Megiddo - the stars fought from heaven - the torrent Kishon swept them (=Israel's enemies) away - (v 21:x3); thus torrent/waters - shooting stars(?) - waters (v 21a-c). Eventually this is followed by sunrise again (5:31b; see Is $64: 1-3)$. These references seem to underline the possibility of the memory 
of global disasters which probably left an indelible impression on the minds of the biblical authors.

\subsubsection{Gideon's loaf of barley bread, a millwheel?}

In another narrative, it is stated that Gideon, eavesdropping, learns from the dream of a member of the enemy camp, that a round, spinning object will strike the tent and bring it to the ground (Jdg 7:12-13). However, the word as it appears as part of the expression in

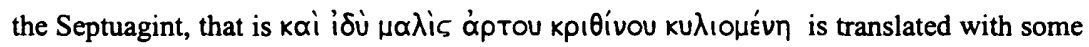
variations by English Versions: a "round", or "flat", "stale loaf/cake of barley bread" or

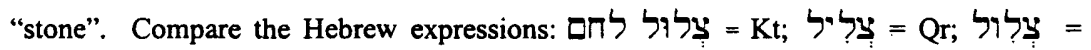
Geniza Fragments. However, the companion of the dreamer interpreted this object as Gideon's "sword".

\subsubsection{An apocalyptic device}

The concept of the mill(-stone/wheel) in the Old Testament generally, but specifically in Joshua apparently represents an apocalyptic device to underscore the grotesque scene of which would later become the time of the End. Joshua did not expect any grand End as presented in later eschatological passages in the Old Testament and New Testament, or e $\mathrm{g}$ in the Ragnarok of Norse myth, the approaching apocalypse (Roberts 1995:82, 97-105). But the presentation probably contains the seeds of such an idea. Isaiah 47:1-15 seems to confirm the association of a millstone/-wheel and disaster in a cosmic context. Verse 2a indicates the millstone (handmill), verse $2 \mathrm{~b}$ refers to water which has to be negotiated, and verse 13 brings the cosmic sphere into the picture. The words of Jeremiah 25:10 in combination with Jeremiah 51:63-64 appear in Revelation 18:21-22. Again it must be noted that a millstone falls into the sea in a context of disaster. In the book of Revelation (18:21) which bears the marks of apocalyptic literature, Babylon is compared to a millstone falling into the sea, as in the myth.

However, Jeremiah compares the steadfastness of the "statutes" (IPT) of the moon and stars with the steadfastness of Yahweh's covenant with Israel (Jr 31:35-37), and the steadfastness of his covenant with day and night, expressed by their regular appearance (Jr 33:19-22). The idea to be noted is the texts' indication that day and night 
constantly come and go. This may be a reaffirmation of the regular movements of the (two) celestial bodies following the exception of this situation recorded in Joshua 10 (cf Jr 5:22; Ps 148:3-6).

\section{LITERARY STRUCTURE AND THEOLOGICAL VIEW}

Against this background, it would seem that an undercurrent of an apocalyptic-eschatological nature informed the passages under discussion. The presentation of Yahweh as Divine Warrior engaging cosmological phenomena to accomplish his purpose bears the typical marks of apocalyptic literature. Hanson (1985:465-488; cf Weinfeld 1984:127, $130,140-141)$ acknowledges that references to e $g$ a star that left its course, that is, a comet which fell out of its fixed place, may be understood in this physical sense in the Bible (see Jdg 5:20). In other places in the Old Testament, references to stars are not considered as references to divine entities, but rather to heavenly bodies which serve as God's emissaries and servants. This is not to deny that stone throwing forms part of Yahweh's weaponry, but the whole scene is set in a mythical-astronomical framework.

The presentation of the material in a way that seems to defy or supersede historical parameters, led some authors to think in theological (deuteronomistic) terms only in an effort and as a way to understand this passage (see De Vaux 1978:632, 634; Boling \& Wright 1982:283). Having criticized all possible explanations to understand the passage De Vaux (1978:634-635), following a theological interpretation, avers that like the hailstorm in verse 11 , the words in verses 12-13 are an expression, in poetry, of the supernatural help that Israel received. Verses 12b-13a represents a poetic expression of Yahweh's help that Israel received, in contrast to the prosaic expression of verses 10-11. Here a comparison with other passages yields the same result. Double accounts of prosaic and poetic style are characteristic of the Old Testament (cf Ex 14 and 15; Jdg 4 and 5). This style can also be seen in Egyptian literature (Kang 1989:158).

A reading of the passage in terms of Yahweh as the Divine Warrior may be confirmed by certain considerations. However, first a word needs to be said about the relationship between the sun and Yahweh. Disregarding the possibility that the sun is presented as a celestial body in the text, Niehr (1990:140-163) and Taylor (1993:92-98; 111-121) have associated the sun with Yahweh in mythical and theological categories. 
They aver that the present passage presents Yahweh as the sun-god, addressed by Joshua as "Sun" (v.12b: שמש (ש). They base their views on Old Testament textual evidence apparently showing a gradual transference of solar features to Yahweh, more or less parallel to a similar development in the surrounding Canaanite area (Baal-Shamem), from the $1^{\text {st }}$ Millennium onwards. However, their views on the relationship between Yahweh and the sun do not alter the understanding of Yahweh as Divine Warrior in the passage.

In connection with the latter, it is clear that the idea of the miraculous intervention of Yahweh in the history of Israel pervades the Old Testament (Boling \& Wright 1982:283). The present passage links the astronomical occurrences directly to Yahweh making war on Israel's enemies (cf v10:13a+b; 10:14a+b). Secondly, the passage presents Yahweh as Divine Warrior who wins the battle (Jos 10:14: יהוה נלחם לישראל) against the background of the divine war (Boling \& Wright 1982:285). Three elements of divine war appear in the passage, namely divine confusion or panic, hailstones from heaven and the stationary position of sun and moon (v10-14; Kang 1989:154-156). Younger (1990:197-237, especially 219-220) explores this phenomenon further and finds that Joshua 10:11-15 reveals the typical ancient Near Eastern transmission code of a military conquest. The ingredients of this code include divine intervention, omen techniques (or rather a polemic against the latter), the limitation of the battle to a single day (which according to him reduces the expression to hyperbole), a literary technique in which a deity is implored to maintain daylight long enough for there to be a victory, and finally, that divine intervention may come in the form of a miracle/sign. Earlier Weinfeld (1984:121-147) had pointed out that comparison with war descriptions in the ancient world shows that divine war themes all have close analogies in the literature of the ancient Near East and also in Greek epic, especially where divine intervention in war is mentioned. These war themes are as follows: God's fire consuming the enemy, stones from heaven thrown upon the enemy, thunder which accompanies God in his battle, the cloud which hides the people from the sight of the enemy, and holding back the progress of the celestial bodies in order to enable a victorious conclusion of the war. The idea of hailstones used as a military weapon by Yahweh, is confirmed by the book of Job, where Yahweh's storage of hail stands in direct relation to his making war on his enemies (38:22b-23). The use of (המם) ויהמם) further supports the view that the passage must be 
understood in theological terms, since this word forms part of the vocabulary of divine war (Ex 14:24; Jdg 4:15; 5:15; 1 Sm 7:10; see Ex 23:27; Dt 7:23, see Job 38:22-23 - De Vaux 1978:632; M Fishbane 1991:389). The theological thrust of the passage is supported by the chiasm which frames the literary unit in Jos 10 (Boling \& Wright 1982: $281,283,285)$.

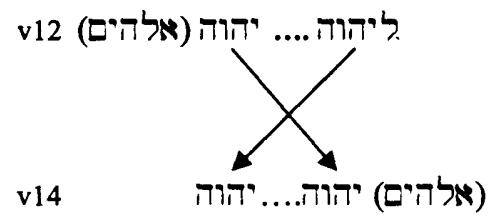

This theological "framework" seems to emphasize that whatever the mythological intrusion in this Old Testament passage may have been, the final precipitation of thought in the text is dominated by a reference to the God of Israel. This view is confirmed by a similar presentation of ideas in other parts of the Old Testament. In Genesis 6:1-4, for example the mythological idea of the gods and human females cohabiting, with all the ideas of supernatural power and even immortality that it entails, frames the main idea in the middle of the passage which focuses on the words of God. Thus, the passage displays a stylistic pattern which may be represented by $B-A-B$, with the emphasis on $A$, the true God speaking, with the heavenly beings, the Nephilim and humans $(B)$ placed around him, in silence (Van Zyl 1989:12).

\section{CONCLUSION}

\subsection{Yahweh's authority}

Whatever the original background of the ancient conjuration in Joshua 10:12, Joshua 10:12-14 stresses Yahweh's authority over the sun and moon. A similar belief is reflected in Job 9:7, Isaiah 38:7-8, and Sirach 46:4 (cf 2 Ki 20:9-11; Sir 48:23), where the sun obeys a man of God (Lipiñski 1995:1449-1450). 


\subsection{Mythical motifs}

Fragments of ancient mythical motifs appear in Joshua and Judges. The text in Joshua 10 represents an example of such a motif. There appears to be evidence in the passage of the memory of cataclysms disguised in mythical garb. The passage apparently made use of a mythical perspective on the outcome of the completion of a cycle of the precession of the equinoxes, adjusted to suit the biblical intention. The millwheel (and its destination) represents that perspective by portraying the idea as the stopping of sun and moon. In the text however, the standstill of sun and moon and the downpour of (hail-) stones and other occurrences (represented by the millstone and the disaster which follows in its wake), have been adjusted to serve as military language to reinforce the representation of Yahweh's actions in terms of the Divine Warrior. Thus the study has hopefully revealed some mythical motifs behind the texts discussed, that is behind the references to celestial bodies serving in the text inter alia as weapons in the hands of the Divine Warrior.

\section{Works Consulted}

Avishur, Y \& Blau, J (eds) 1978. Researches in the Bible and in the ancient Near East: On the seventieth birthday of $S$ E Loewenstamm. Jerusalem: E Rubinstein's Publishing House.

Bauval, R \& Gilbert, A 1996. The Orion mystery. London: Mandarin.

Boling, R G \& Wright, G E 1982. Joshua. The Anchor Bible. New York: Doubleday \& Company.

Childs, B S 1979. Introdiction to the Old Testament as Scripture. London: SCM.

Claassen, W (ed) 1988. Text and Context: Old Testament and Semitic Studies for F C Fensham. JSOT 48. Sheffield: Academic Press.

Coats, G W (ed) 1985. Saga, legend, tale, novella, fable: Narrative forms in Old Testament literature. Sheffield: JSOT Press.

Cohen, M 1988. The canonical lamentations of ancient Mesopotamia. Potomac, Md: Capital Decisions.

Collins, A 1998. Gods of Eden. London: Headline.

Cotterell, A 1996. Encyclopedia of mythology. London: Lorenz Books. 
De Santillana, G \& Von Dechend, H 1969. Hamlet's Mill: An essay on myth and the frame of time. Ipswich: Gambit.

De Vaux, R 1978. The early history of Israel to the period of the Judges, Vol II, tr by D Smith. London: Darton, Longman \& Todd.

Durham, J I 1987. Exodus in Hubbard et al (eds) 1987:270.

Ellis-Davidson, H R 1996. Viking and Norse mythology: Library of the world's myths and legends. London: Chancellor.

Fishbane, M 1991. Biblical interpretation in ancient Israel. Oxford: Clarendon.

Gribbin, J \& Goodwin, S 1997. Origins - Our place in Hubble's Universe. London: Constable.

Hancock, G 1996. Fingerprints of the gods. A quest for the beginning and the end. London: Mandarin.

Hanson, P D 1985. Apocalyptic literature in Knight \& Tucker (eds) 1985:465-488.

Hartner, W 1965. The earliest history of the constellations in the Near East and the motif of the lion-bull combat. JNES 24(1/2), 1-16.

Hayes, J H \& Miller J M 1977. Israelite and Judaean history. London: SCM.

Heyns, D 1997. Of plumb lines, gnomons and sundials: Reviewing ancient Israel's measuring of space and time. OTE 10(2), 252-267.

Hubbard, D A et al (eds) 1987. Exodus. Waco, Texas: Word Books. (Word Biblical Commentary.)

Jordan, M 1995. Myths of the World. London: Cathie Ltd.

Kang, Sa-Moon 1989. Divine War in the Old Testament and in the ancient Near East. Berlin: W. de Gruyter.

Knight, D A \& Tucker, G M (eds). The Hebrew Bible and its Modern Interpreters. Chico, CA: Scholars Press.

Kroll, W (ed) 1921. Paulys Realencyclopädie der Classischen Altertumswissenschaft, Bd XXI. Stuttgart: A Druckenmüller.

Kruger, H A J 1998. Old age frailty versus cosmic deterioration? A few remarks on the interpretation of Qohelet 11,7-12,8, in Schoors (ed) 1998:399-411.

LaSor, W.S, Hubbard, D A \& Bush, F W 1982. Old Testament Survey. Grand Rapids, Michigan: Eerdmans. 
Leaf, W \& Bayfield, M A 1971. The liad of Homer, Vol I. London: Macmillan.

Lipiñski, E 1995. s v SHEMESH שמש, in Van der Toorn K et al (eds) 1995: 1449-1450.

Magnusson, M (èd) 1996. Chambers Biographical Dictionary.

Metford, J C J 1983. Dictionary of Christian lore and legend. London: Thames and Hudson.

Millard, A R 1994 et al (eds) Faith, tradition, and history. Old Testament historiography in its Near Eastern context. Winona Lake, Indiana: Eisenbrauns.

Neff, R W 1985. Saga, in Coats (ed) 1985:17-32.

Niehr, H 1990. Der höchste Gott: Alttestamentlicher JHWH-Glaube im Kontext syrischkanaanäischer Religion des 1. Jahrtausends v. Chr. Berlin: De Gruyter.

Page, R I 1990. Norse myths. London: British Museum Press.

Pearsall, J \& Trumble, B (eds) 1996. The Oxford English Reference Dictionary.

Procter, P (ed) 1995. s v "axis" in The Cambridge International Dictionary of English.

Roberts, M J 1995. Norse gods and heroes: Myths of the world. New York: Metro Books.

Ronan, C A 1991. The natural history of the universe. London: Doubleday.

Rimmer, H 1952. The harmony of science and Scripture. Grand Rapids, Michigan: Eerdmans.

Sawyer, J F A 1972. Joshua 10:12-14 and the solar eclipse of 30 September 1131 BC, PEQ 104, 139-146.

Schoors, A (ed) 1998. Qohelet in the Context of Wisdom. Leuven: University Press. (Bibliotheca Ephemeridum Theologicarum Lovaniensium, CXXXVI.)

Soggin, J A 1972. Joshua. OTL, tr by R A Wilson. London: SCM.

Spence, $\mathrm{P}$ et al (eds) 1997. Astronomy now, monthly night sky guide. Kent. $\mathrm{s} 1$.

Tadmor, H \& Weinfeld, M (eds) History, historiography and interpretation. Jerusalem: Magnes Press.

Taylor, J G 1993. Yahweh and the Sun: Biblical and archaeological evidence for sun worship in ancient Israel. Sheffield: Academic Press.

Van der Toorn, $\mathrm{K}$ et al (eds) Dictionary of deities and demons in the Bible. Leiden: $\mathrm{E} \mathrm{J}$ Brill.

Van der Woude, A S 1988. Zion as Primeval Stone in Claassen (ed) 1988:237-248. 
Van Zyl, A H (ed) 1989. Genesis. Die Verklarende Bybel. Cape Town: Lux Verbi.

Walton, J H 1994. Joshua 10:12-15 and Mesopotamian celestial omen texts, in Millard et al (eds) 1994:181-190.

Weinfeld, M 1978. Divine war in ancient Israel and in the ancient Near East, in Avishur \& Blau (eds) 1978: 171-181, 214.

- 1984. Divine intervention in war in ancient Israel and in the ancient Near East, in Tadmor \& Weinfeld (eds) 1984:121-147.

Willcock, M M 1970. A commentary on Homer's Iliad, Books I-II. London: Macmillan.

Wilson, C 1997. From Atlantis to the Sphinx: Recovering the lost wisdom of the ancient world. London: Virgin.

Wissowa, G et al (eds) 1896. Paulys Realencyclopädie der Classischen Altertumswissenschaft, Bd IV. Stuttgart: A Druckenmüller.

Younger, K L 1990. Ancient conquest accounts: $A$ study in ancient Near Eastern and Biblical history writing. JSOT 98. Sheffield: Academic Press.

Ziegler, K \& Sontheimer, W (eds) 1964. Der Kleine Paulus. Stuttgart: A Druckenmüller. (Lexikon der Antike, Bd I.) 